\title{
Nieznany przekład Roty na język karaimski
}

\author{
Anna Sulimowicz \\ Uniwersytet Warszawski, Wydział Orientalistyczny \\ Zakład Turkologii i Ludów Azji Środkowej
}

\begin{abstract}
An Unknown Translation of Rota into the Karaim Language
Summary: The oldest known translations of Polish literature into the Karaim language date back to the $17^{\text {th }}$ century. Among those poets whose works have been translated we find Jan Kochanowski and Adam Mickiewicz. Another Polish author that can be read in Karaim is Maria Konopnicka. A translation of her poem Rota (The Oath) was recently discovered in the Józef Sulimowicz manuscript collection. The translator was Leon Eszwowicz, who taught religion to Karaite children in Halicz. Although his translation is not of great or significant literary value, it remains an interesting example of the interest shown by Karaites in Polish literature.
\end{abstract}

Keywords: Karaites, Karaites in Halicz, Karaim literature, Polish literature in translation, Karaim language

Najstarsze znane przekłady literatury polskiej na język karaimski pochodzą prawdopodobnie z wieku XVII. Są to przełożone przez Zaracha ben Natana z Trok (1505-1663) pieśń Jana Kochanowskiego Czego chcesz od nas, Panie, za Twe hojne dary (karaim. Ne klejsiń bizd’ań, T́eńrim, jaxšyłyyyj üčuń) ${ }^{1}$ oraz niezidentyfikowana

1 Opublikowany po raz pierwszy drukiem przez Z. Abrahamowicza w Two Religious Poems by the Polish $16^{\text {th }}$ Century Poet Jan Kochanowski in Karaite, „Bulletin d'Études Karaïtes" 1989, z. 2, s. 71-72. 
pieśń polska². Do najdawniejszych, bo z początku wieku XVIII, należy także przekład Psalmu 91 dokonany przez Szełomo ben Aharona z Poswola (1670?-1745) na podstawie, co interesujące, nie oryginału hebrajskiego, lecz wersji polskiej Jana Kochanowskiego Kto sie w opieke poda Panu swemu (karaim. Kim symarłansa). ${ }^{3}$ A. Zajączkowski wspomina o zachowanych w rękopiśmiennych odpisach przekładach wierszy St. Trembeckiego ${ }^{4}$, których tłumaczem miał być Aben Jaszar, czyli Abraham ben Josef Szełomo Łucki (1792-1855), lecz utworów tych nie udało się zidentyfikować.

W rękopisie pozostaje też pierwszych pięć ksiąg Pana Tadeusza przełożonych przez Józefa Łobanosa (1878-1947), który pracę nad przekładem rozpoczął w końcu lat 30.5 , jedynie Inwokacja została opublikowana drukiem na łamach czasopisma historyczno-społeczno-kulturalnego Związku Karaimów Polskich "Awazymyz" ${ }^{6}$ Z okresu międzywojennego pochodzą także przekłady innych utworów Mickiewicza. Szymon (Szemaja) Firkowicz (1897-1981) przetłumaczył

2 A. Dubiński, Przekłady literatury polskiej w piśmiennictwie karaimskim, „Przegląd Orientalistyczny” 1975, 4 (96), s. 403; R. Leszczyński, Wiersze Jana Kochanowskiego $w$ przekładach na jezyk karaimski, [w:] Poeta $z$ Czarnolasu. W czterechsetna rocznice śmierci Jana Kochanowskiego, red. P. Buchwald-Pelcowa, J. Pacławski, Radom 1984, s. 54.

3 Przekład ten szczegółowej analizie poddał Z. Abrahamowicz w Two Religious Poems by the Polish $16^{\text {th }}$ Century Poet Jan Kochanowski in Karaite, "Bulletin d'Études Karaïtes” 1989, z. 2, s. 73-78. Karaimski tekst Psalmu 91 był publikowany przez T. Kowalskiego w Karaimische Texte im Dialekt von Troki, Kraków 1929, s. 53-54, A. Mardkowicza w Zemerler. Pieśni religijne Karaimów, Łuck 1930, s. 5-6 oraz S. Firkowicza w Koltchałar. Krótkie modlitwy karaimskie, Wilno 1935, s. 30-31. Warto dodać, że utwór ten jest nadal wykonywany przez Karaimów w Polsce i na Litwie podczas nabożeństw i uroczystości religijnych.

4 A. Zajączkowski, Die karaimische Literatur, [w:] Philologiae Turcicae Fundamenta, t. II, red. L. Bazin, A. Bombacı, J. Deny, T. Gökbilgin, F. İz, H. Scheel, P. N. Boratav, Wiesbaden 1964, s. 796.

5 Pracę nad przekładem Pana Tadeusza J. Łobanos rozpoczął 6 października 1938 r., niestety, przedsięwzięcia tego nie zdołał doprowadzić do końca. $\mathrm{Z}$ jego tłumaczeniem wiąże się pewna anegdota. Otóż zachwycona urodą strof w języku karaimskim jedna z Karaimek zawołała ponoć: „To jest takie piękne, to trzeba koniecznie przetłumaczyć na polski!”.

6 „Awazymyz” 2004, z. 1 (8), s. 6. 
Odé do młodości $i^{7}$, ballady Trzech budrysów ${ }^{8}$ i Rybkę oraz sonet Droga nad przepaścia $w$ Czufut Kale $e^{10}$. Tenże sonet ${ }^{11}$ wraz z sześcioma innymi Sonetami krymskimi ukazał się w przekładzie Ananiasza Zajączkowskiego (1903-1970) w „Karaj Awazy"12. Wydawca czasopisma, Aleksander Mardkowicz (1875-1944) opublikował również własne tłumaczenie innego dzieła Mickiewicza - ballady Alpuchara z poematu Konrad Wallenrod ${ }^{13}$.

W spuściźnie po zmarłym młodo poecie, Zachariaszu Abrahamowiczu (1878-1903) z Halicza znajdują się przekłady popularnych pieśni polskich: $Z d y$ mem pożarów (Choral), Hej orle, orle, Boże, coś Polske, Boże Ojcze, twoje dzieci oraz Hanuz Karajłar eksiłmed' wzorowana na Mazurku Dąbrowskiego. Wszystkie zostały opublikowane wraz z oryginalnymi utworami Abrahamowicza na łamach „Karaj Awazy”. ${ }^{14}$

Do tej listy świadectw recepcji literatury polskiej w piśmiennictwie karaimskim można dodać przekład Roty z kolekcji rękopisów zgromadzonej przez turkologa Józefa Sulimowicza (1913-1973), na który natrafiono podczas prac nad projektem „Katalog rękopisów i starodruków karaimskich” realizowanym dzięki grantowi Narodowego Centrum Nauki. ${ }^{15}$

7 Ir avazy igitlik'k'a, [w:] T. Kowalski, Karaimische Texte..., s. 76-78; Ir-awazy igit'likkia, „Coś” 1979, z. 2, s. 6-11; Machtaw iry igitlikkia, [w:] Bir kiuń édi... Buvo tokia diena..., red. H. Kobeckaitè, K. Firkavičiutè, Vilnius 2015, s. 199-201.

8 Ücz budrys, „Coś” 1979, z. 1, s. 6-9; Ǚ̌ budris, [w:] Bir kiuń édi..., s. 206-207.

9 Balyčech, [w:] Bir kiuń èdi..., s. 207-205.

10 Joł kała iuśtiunia, „Myśl Karaimska” 1925, t. 1, z. 2, s. 24; Iol Kała üśtuńa, [w:] T. Kowalski, op. cit., s. 78.

11 Joł Kaleniń jary üśtuńa, „Karaj Awazy” 1931, z. 2, s. 14. Przedruk: „Awazymyz” 2005, z. 2 (11), s. 6.

12 Czatyrdah, „Karaj Awazy” 1931, z. 1, s. 11; Bachczesaraj, ibidem, s. 12; Haremniń źer'at'lari [Mogiły haremu], ibidem, s. 13; Tawłaryn k'or'um'u G'ozlewe jyłhałyhyndan [Widok gór ze stepów Kozłowa], „Karaj Awazy” 1931, z. 2, s. 15; Jołczu [Pielgrzym], ibidem, s. 16; Bachczesaraj k’ecz’alej [Bakczysaraj w nocy], ibidem, s. 17.

13 Alpuhara. Adam Mickiewicznin balladasy azat kecirmeginde Al-Marnyn [Alpuhara. Ballada Adama Mickiewicza w wolnym przekładzie Al-Mar], „Karaj Awazy” 1935, z. 8, s. 8.

14 Ułlu titinbe (Z dymem pożarów), „Karaj Awazy” 1931, z. 2, s. 25; Ej neszer, neszer (Hej orle, orle), ibidem; Tenrim, senin ułanłaryn... (Boże, Ojcze, Twoje dzieci), ibidem, s. 26; Tenrim, ki biźnin atałarymyzny... (Boże, coś Polskę), ibidem, s. 26-27; Hanuz Karajłar eksiłmed, ibidem. Ta ostatnia została przedrukowana w pisemku „Coś” jako Hanuz Karajłar eksilmed'. Pieśn na wzór „Jeszcze Polska nie zginęła” („Coś” 1979, z. 2, s. 15).

15 Grant nr DEC-2011/03/D/HS2/00618. 


\section{Rękopis}

Numer katalogowy JSul.I.49.44. Pojedyncza karta o wym. $210 \times 170$ mm zapisana jednostronnie (na rewersie obliczenia ołówkiem kopiowym), 18 wierszy na stronie. Papier współczesny, zżółkły. Brzegi lekko nierówne, drobne naddarcia, ślady zginania. Atrament niebieski. Pismo hebrajskie (półkursywa), wokalizowane, staranne. Język karaimski (dialekt południowozachodni).

Adnotacja ołówkiem ręką Józefa Sulimowicza: „Rota” / Tłumaczył R[ib]bi Leon Eszwowicz / 1924 r.

Porównanie z innymi rękopisami Leona Eszwowicza (tekstami referatów wygłaszanych przez Eszwowicza w latach 30. XX w. na zebraniach Koła Pań Karaimskich w Haliczu, zwłaszcza z rękopisami nr inw. JSul.VI.08.43 i JSul.VI.08.45, opatrzonymi podpisem autora) potwierdza, że rękopis wyszedł spod jego ręki. Nieznane są okoliczności, w jakich trafił on w ręce Józefa Sulimowicza. Znajduje się w teczce zawierającej 50 różnych drobnych (w przeważającej większości złożonych z 1 lub 2 kart) rękopisów pochodzących zarówno z Halicza (różnego rodzaju teksty religijne i okolicznościowe), jak i z Krymu (m.in. fragmenty medżuma, modlitwy za zmarłych, listy prywatne), a także z Wilna oraz prawdopodobnie z Łucka. Józef Sulimowicz, Karaim z Halicza, znał osobiście kopistę (prawdopodobnie był nawet jego uczniem), podaną przez niego informację dotyczącą autora i czasu powstania przekładu można więc przyjąć za pewnik.

\section{O tłumaczu}

Halicki Karaim, Leon (Lewi) Eszwowicz urodził się 16 lutego 1887 r. Jego rodzicami byli Samuel syn Jehudy Eszwowicz (1861-1942) i Estera z Nowachowiczów (1860-1931), siostra Szałoma Nowachowicza, hazzana w latach 1900-1922. Babka Leona po kądzieli, Sara z domu Samuelowicz (1829-1895) wywodziła się z rodu XVII-wiecznego karaimskiego uczonego, Josefa syna Szemoeła Hamaszbira, przybyłego z Derażna na Wołyniu odnowiciela religii i życia społecznego wśród Karaimów w Haliczu po powstaniach Chmielnickiego. Koligacje są w tym wypadku istotne, gdyż w gminie halickiej osoby pełniące funkcję hazzana tradycyjnie wywodziły się z rodu Hammaszbira lub z rodzin będących jej bocznymi odgałęzieniami (Leonowicze, Mordkowicze), a wiele wskazuje na to, że Leona Eszwowicza przygotowywano do objęcia w dalszej perspektywie tej funkcji. Otrzymał staranne wykształcenie religijne. Pierwsze nauki pobierał na miejscu, w Haliczu, zapewne od wuja, Szałoma Nowachowicza, a następnie, idąc w jego ślady, wyjechał na Krym, by kontynuować studia w Wyższej 
Karaimskiej Szkole Duchownej w Eupatorii kierowanej przez Ilię Ilicza Kazasa. Niestety, w rodzinnych archiwach nie zachowały się żadne dokumenty mogące rzucić więcej światła na ten okres w życiu Eszwowicza. Bez wątpienia jednak nauka w tej uczelni, będącej pierwsza karaimską szkołą religijną zapewniającą równolegle wykształcenie ogólne, a także postać jej założyciela, I. I. Kazasa, wywarły nań silny wpływ.

Choć Eszwowicz posiadał stosowne wykształcenie, nie ubiegał się o stanowisko hazzana wakujące po śmierci Szałoma Nowachowicza w 1922 r. ani też w roku 1924 czy później, w 1933, gdy Izaak Abrahamowicz ustąpił z tego stanowiska. Przyczyną tego mógł być fakt, że pozostał w stanie bezżennym, a od hazzana wymagano, by był żonaty. Zdobytą w Eupatorii wiedzę wykorzystywał ucząc religii karaimskie dzieci i młodzież - w zamieszczonej w pierwszym numerze „Myśli Karaimskiej” notatce figuruje jako „Leo Eszwowicz, nauczyciel religji karaimskiej” ${ }^{16}$. W początkach lat 20. XX w. gmina w Haliczu, wspierana przez Jana Grzegorzewskiego, podjęła starania o prowadzenie lekcji religii dla karaimskich uczniów w miejscowej szkole. Zabiegi te zostały uwieńczone sukcesem i wiosną 1924 r. Ministerstwo Wyznań i Oświecenia Publicznego wydało zgodę na ustanowienie nieetatowego nauczyciela tego przedmiotu od 1 września 1924 r. Do konkursu na to stanowisko stanęli: Leon Eszwowicz oraz Marek Leonowicz (1885-1940) ${ }^{17}$. Ten ostatni krótko przed wybuchem I wojny światowej uczył już religii, gdy poprzedni mełamed (nauczyciel w szkółce religijnej), Jakub Józef Leonowicz (1848 - po 1917) wyjechał do Łucka, by objąć tam stanowisko hazzana ${ }^{18}$. Po wycofaniu swojej kandydatury przez Leonowicza, jedynym kandydatem pozostał Eszwowicz, który został zatwierdzony na tym stanowisku przez Radę Szkolną w Stanisławowie. Niestety, wkrótce stanowisko nauczyciela religii karaimskiej przy 7-klasowej szkole w Haliczu zlikwidowano, motywując to brakiem wystarczającej liczby uczniów tego wyznania. Gdy w kwietniu 1925 r. staraniem hazzana Izaaka Abrahamowicza utworzono w Haliczu szkółkę parafialną „do której uczęszczają wszystkie bez wyjątku dzieci w wieku szkolnym płci obojga" ${ }^{\prime \prime}$, przez pewien czas w niej nauczał. Jego

\footnotetext{
16 Halicz, „Myśl Karaimska” 1924, t. I, z. 1, s. 34.

17 Z. Zarachowicz, Nauczanie religji karaimskiej, „Myśl Karaimska” 1925, t. I, z. 2, s. 41-42.

18 Z. Zarachowicz, Listy z Halicza, „Myśl Karaimska” 1924, t. I, z. 1, s. 29.

19 Z[arach] Z[arachowicz], Otwarcie szkoły parafialnej, „Myśl Karaimska” 1926, t. I, z. 3, s. 26.
} 
uczennicą była Sabina z Eszwowiczów Nowicka (1910-2007), wedle relacji której Eszwowicz „był bardzo nerwowy” i niechętnie pełnił funkcję mełameda ${ }^{20}$.

W notatkach Jana Grzegorzewskiego, częściowo opublikowanych przez T. Kowalskiego, znajduje się powiedzenie iaksy ićki xor sawut ićin beryen 'dobry napój w podłem naczyniu podany', z dodanym objaśnieniem „o uczonym, a milczącym Eszwowiczu" ${ }^{21}$. Niestety, nie wiadomo, kiedy zostało ono zanotowane, możemy więc jedynie spekulować, czy owym Eszwowiczem mógł być właśnie Leon.

W 1932 r. ułfu hazzan Szymon Firkowicz wystosował list do gminy w Haliczu, wyrażając w nim swój niepokój z powodu braku lekcji religii i języka hebrajskiego w Haliczu ${ }^{22}$ - można stąd wnioskować, że w tym okresie Eszwowicz zrezygnował z nauczania. Mieszkał w Załukwi, gdzie wraz z młodszym bratem, Mojżeszem (1889-1967) gospodarował na roli.

Nie wycofał się jednak całkowicie z życia społeczno-kulturalnego halickiej gminy. Na zebraniach Koła Pań Karaimskich, którego prezeską była Sabina z Samuelowiczów Nowachowiczowa, jego cioteczna siostra (ich matki były siostrami bliźniaczkami), wygłosił kilka referatów o tematyce religijnej i historycznej ${ }^{23}$. Był współorganizatorem uroczystego spotkania Koła w dniu 4 lutego 1934 r. dla upamiętnienia 100 rocznicy urodzin I. I. Kazasa. Przedstawił na nim życiorys zasłużonego pedagoga i swojego nauczyciela ${ }^{24}$ oraz odczytał ułożoną przez siebie mowę żałobną ku jego czci²5. Wszystkie jego wystąpienia, jak można wnosić z zachowanych rękopisów i sprawozdań Koła, wygłaszane były w języku karaimskim, którego zachowanie i krzewienie jego znajomości było jednym z celów Koła.

20 Informacja osobista, $2006 \mathrm{r}$.

21 T. Kowalski, Materjały karaimskie ś. p. Jana Grzegorzewskiego, „Myśl Karaimska” 1932-1934, t. 10, z. 10, s. 24.

22 Biblioteka Wróblewskich Litewskiej Akademii Nauk w Wilnie, sygn. f. 301-410, k. 88.

23 Zob. inny artykuł autorki, Działalność społeczna i edukacyjna Koła Pań Karaimskich w Haliczu w tym numerze „Almanachu Karaimskiego”.

24 Uksasy tirlikłerinin ribbi Elijahu Kazaznyn of tync sahyncy anyn ałhyska, Archiwum Koła Pań Karaimskich w Haliczu, nr inw. JSul.VI.08.13.02. W zamieszczonej w „Karaj Awazy” notatce o akademii ku czci Kazasa (Dzymatynda Halicnin, „Karaj Awazy” 1934, z. 7, s. 25, autor nie podany, najprawdopodobniej Z. Zarachowicz, maszynopis notatki zachował się w Archiwum Koła, nr inw. JSul.VI.08.13.06) podano inny tytuł: „Ribbi Elijahu Kazas - jiwretiwcisi Karajłarnyn”, bez wątpienia jednak chodzi o ten sam tekst.

25 [Kyna ki uxudum any], nr inw. JSul.VI.08.13.03. 


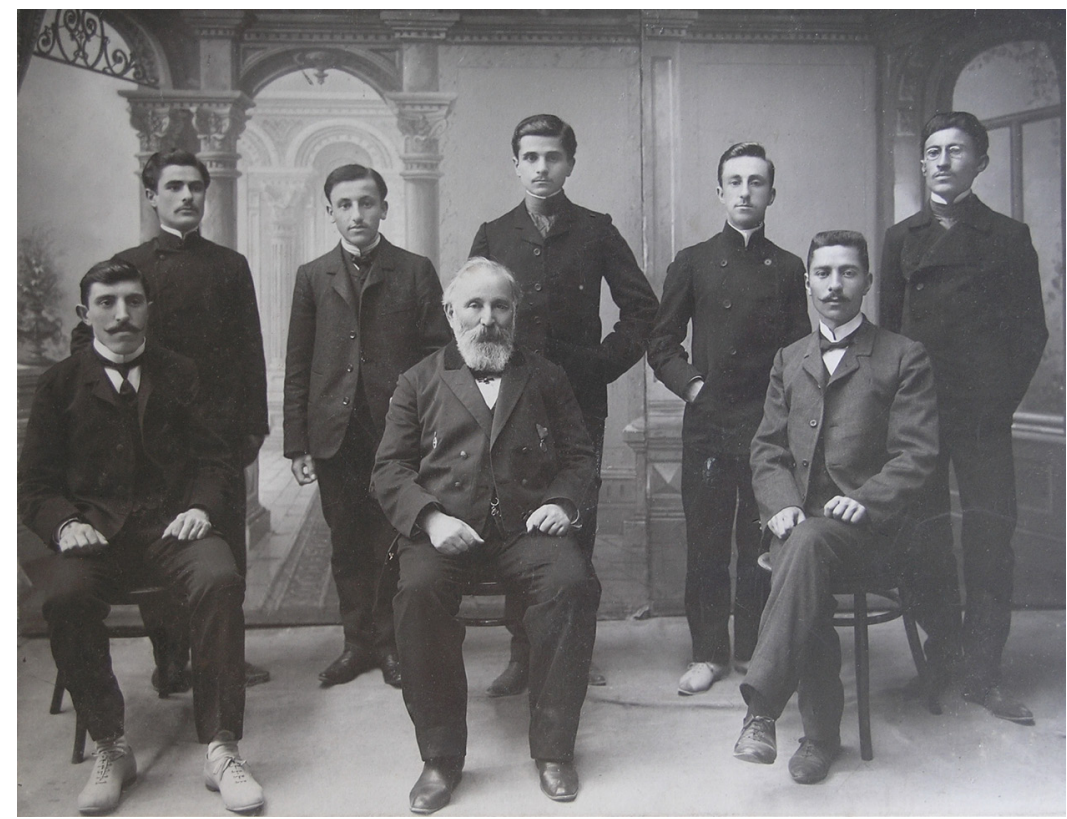

Ryc. I. I. I. Kazas z uczniami. Pierwszy z lewej siedzi Leon Eszwowicz. Eupatoria, pierwsza dekada XX w.

W tym miejscu warto wspomnieć o interesującym świadectwie lingwistycznych zainteresowań i naukowego zacięcia Eszwowicza. W 1903 r. dziennikarz i krajoznawca, Grzegorz Smólski (1844-1911) opublikował na łamach czasopisma „Naokoło Świata” relację ze spotkania z zamieszkałymi w Haliczu Karaimami ${ }^{26}$. Podczas wizyty u karaimskich gospodarzy, Samuela i Racheli Eszłowiczów (sic!), uwagę dziennikarza zwróciły zapiski ich syna, Leona, zawierające opis gramatyki oraz słowniczek języka karaimskiego. Smólski tak opisuje młodego Karaima: „(..) stanął przede mną piękny, szesnastoletni chłopak, brunet z czarnemi jak węgiel, błyskotliwemi oczyma i nadzwyczaj inteligentnym wyrazem twarzy. Po polsku mówił bardzo dobrze i poprawnie. - Napisałem sobie to w wolnym czasie - mówił mi. - W tym roku już nie uczęszczam do szkoły, skończywszy

26 G. Smólski, U Karaimów w Haliczu, „Naokoło Świata” 1903, z. 2, s. 465-467, 482-484, 506-507, 522-253, 538-540, 546-548, 564-565. Przedruk w: Almanach karaimski, red. M. Abkowicz, A. Sulimowicz, [Wrocław] 2007, s. 71-84. 
w zeszłym roku szóstą klasę. Wolnego czasu mam dość, bez zajęcia nudzi mi się, więc czytam i piszę sobie"27.

Wydaje się, że inspiracją dla tych zainteresowań były spotkania z orientalistą Janem Grzegorzewskim (1849-1922), badaczem Karaimów i autorem dwóch rozpraw o dialekcie halickim języka karaimskiego. Przebywał on w Haliczu kilkakrotnie, spędził tam też dłuższy czas tuż przed swoją śmiercią. W swych pracach $^{28}$ Grzegorzewski nie wymienia, co prawda, nazwiska Eszwowicza jako swego informatora - w roku 1896, gdy Grzegorzewski zbierał pierwsze próbki języka, Eszwowicz był po prostu za młody, ale bez wątpienia miał z nim styczność podczas późniejszych pobytów w Haliczu. W swej ostatniej woli spisanej 20 września 1922 r. zapisał mu gramatykę arabską"29.

Leon Eszwowicz zmarł w Załukwi w 1947 r. Nie udało mi się ustalić daty dziennej jego zgonu. Pochowany został na miejscowym cmentarzu karaimskim w grobie ziemnym, bez nagrobka.

\section{Transkrypcja i tłumaczenie tekstu}

[1] tasłamabyz of jerni coharahymyzny

nie porzucimy tej ziemi, naszego źródła

[2] bermebiz batma seźimizǵe biźin!

[3] biz ułusu esawnyn, ułusu edomnun

[4] ševet bijik jiwden

[5] bermebiz kyjnałma dusmanha,

[6] ałaj bołuskun biźǵe oł tendri! nie damy zatonąć naszej mowie my, lud Ezawa [lud polski], lud Edomu plemię z wysokiego domu nie damy wrogowi dręczyć [nas] tak pomagaj nam Boże

27 G. Smólski, op. cit., „Almanach Karaimski”, s. 80.

$28 \mathrm{~J}$. Grzegorzewski, Ein turk-tatarischer Dialekt in Galizien: Vokalharmonie in den entt lehnten Wortern der karaitischen Sprache in Halicz, „Sitzungsberichte der Kaiserlichen Akademie der Wissenschaften in Wien, Philosophisch-historische Klasse" 1903, t. 146, s. 1-80; Caraimica: Język Each-Karaitów: Narzecze południowe (luckohalickie), „Rocznik Orientalistyczny” 1914-1918, t. 1-2, s. 252-296; Narzecze poludniowe Karaitów polskich, czyli tzw. Łach-karaitów, „Sprawozdania z czynności i posiedzeń Akademii Umiejętności w Krakowie” 1917, t. 22, s. 2-6.

29 Dokument z sądu powiatowego w Haliczu oddział II z 19 kwietnia 1924 r. Materiały po J. Grzegorzewskim w kolekcji J. Sulimowicza. 
[7] oł sondrahy kanhadejin

[8] kalkanłabyz zanymyzny biźin syndyrmaktan!

[9] ajłanmastan burun toprakka

[10] taułu of dusmannyn gufka!

[11] har bosaha biźǵe beklikḱke

[12] ałaj bołhaj tendri sakławha

[13] titirmesti ol dusman jizłerǵe

[14] ajłandyrmasty uwułłarymyzny biźin cajałarha!

[15] kyłyc beła turar jyjynymyz biźin

[16] ḱenderir biźin beła zanymyz biźin!

[17] barybyz eǵer tartyłsa miwizimizǵe biźin

[18] ałaj bołuskaj tendrimiz biźin. do ostatniej krwi będziemy bronić naszą duszę przed złamaniem zanim obróci się w proch wraża burza [uderzająca?] w ciało ${ }^{30}$ każdy próg nam twierdzą tak niech będzie Bóg strażą

nie będzie pluł wróg w twarze nie zamieni naszych synów w zuchwalców z mieczem stanie nasza gromada poprowadzi nas nasza dusza pójdziemy, jeśli zostanie zatrąbione w nasz róg tak niech pomaga nasz Bóg

\section{Ekwiwalentność tłumaczenia}

Rota, wiersz napisany przez Marię Konopnicką jako protest przeciwko germanizacyjnej polityce władz niemieckich wobec Polaków w zaborze pruskim ${ }^{31}$, składa się z czterech zwrotek, z których trzy pierwsze stały się słowami popularnej pieśni patriotycznej z muzyką Feliksa Nowowiejskiego. Przekład Eszwowicza obejmuje te właśnie zwrotki, stąd można przyjąć, że stanowi przekład pieśni, a nie literackiego oryginału. Jednakże w przeciwieństwie do pieśni ostatni wers stanowiący refren nie jest w tłumaczeniu powtarzany, zachowana zostaje więc sześciowersowa strofa jak w literackim oryginale.

W przekładzie nie zostały zachowane metrum ani rymy - w oryginalnej sekstynie zbudowanej z wiersza sylabotonicznego jambicznego cztery pierwsze wersy zawierają rymy krzyżowe, piaty i szósty zaś parzyste w układzie $a b a b c c$, ani też długość wersów - w wierszu Konopnickiej nieparzyste wersy

30 Niezupełnie jasne. Można byłoby się spodziewać, że Eszwowicz użyje w tym miejscu muftka 'próżno', w znaczeniu 'w niwecz'.

31 Opublikowana została po raz pierwszy w 11 numerze krakowskiego miesięcznika społeczno-oświatowego „Przodownica” z 1908 r. 
są ośmiozgłoskowe, drugi i czwarty - siedmiozgłoskowe, szósty zaś sześciozgłoskowy. Tłumaczenie zaś jest pozbawione rymu, a liczba zgłosek w poszczególnych wersach jest nieregularna i waha się od sześciu do siedemnastu.

Mogłoby to wskazywać, że mamy do czynienia z metafrazą. Tak jednak nie jest. W odróżnieniu od oryginału stanowiący refren szósty wers nie jest identyczny w każdej zwrotce, lecz nieco zmodyfikowany - zamiast powtarzanego „Tak nam dopomóż Bóg” mamy: [6] ałaj bołuskun biźǵe of Tendri 'tak pomagaj nam Boże', [12] ałaj bołhaj Tendri sakławha 'tak niech będzie Bóg strażąa i [18] ałaj bołuskaj Tendrimiz biźin 'tak niech pomaga nasz Bóg'. W ostatniej zwrotce pojawia się nieobecna w oryginale epifora w postaci zaimka dzierżawczego biźnin 'nasz' na końcu wersów 15-18.

Na tym różnice się nie kończą. Do drobnych odstępstw, które jednakże pozostają bliskie oryginałowi, możemy zaliczyć 'ród' w wersie 1 przetłumaczony jako coharak 'źródło', a nie uruw 'ród, plemię, pochodzenie, rodzina, pokolenie '32, lub jak w wersie 4 ševet hebr. שֶֶׁ 'plemię’. W wersach 8 i 17 „duch” - jako zan 'dusza, serce', choć do dyspozycji jest ałhem 'duch, natchnienie, zapał'. „Pogrześć” w wersie 2 zostało przełożone jako batma 'zanurzać się, nurkować, tonąć / zapadać się, grzęznąć; w tym kontekście wydaje się to jednak w większym stopniu równoważne semantycznie niż dokładniejsze słownikowe odpowiedniki: astrama 'chować, ukrywać / grzebać' lub kemme 'zakopywać, zagrzebywać / grzebać).

W trzecim wierszu oryginału („polski my naród, polski lud”) para pojęć naród - lud została oddana jednym słowem: ułus 'lud, naród'. Choć mogłyby to być ułus i np. chałk 'lud' lub ef 'ludzie, lud', albo znany np. z Hanuz Karajłar eksiłmid' Abrahamowicza $^{33}$ umma (ummet) 'gmina, lud | ludność. Interesująco przedstawia się przekład przymiotnika 'polski', powtarzającego się w oryginale dwukrotnie. Przez Eszwowicza został on oddany przez dwa różne, aczkolwiek powiązane ze sobą określenia: Esaw (ułusu Esawnyn) i Edom (ułusu Edomnun). Pierwsze odnotowuje Kowalski jako 'Ezaw | Polacy, polski’34, Mardkowicz zaś podaje znaczenie 'dziedzic, pan, Polak'35. Biblijny Ezaw, syn Jakuba, inaczej Edom ${ }^{36}$,

32 Objaśnienia znaczeń wyrazów karaimskich według Karaimsko-russko-pol'skij slovar', red. N. A. Baskakov, A. Zajączkowski, S. M. Szapszał, Moskwa 1974. Dalej jako KRPS.

33 Por. refren: Siwiśniz, Karajłar, chaz eźg'e ummałar, „Karaj Awazy” 1931, z. 2, s. 24.

34 T. Kowalski, Karaimische texte im Dialekt von Troki (Teksty karaimskie w narzeczu trockim), Prace Komisji Orjentalistycznej Polskiej Akademji Umiejętności, nr 11, Kraków 1929, s. 185.

35 A. Mardkowicz, Karaj sez-bitigi. Stownik karaimski. Karaimisches Wörterbuch, Łuck 1935, s. 24. Co ciekawe, w KRPS pominięto podane przez Mardkowicza znaczenia 'dziedzic, pan', uznając je widocznie za mało wiarygodne.

36 Księga Rodzaju, 38, 8. 
występuje w literaturze rabinicznej jako peryfraza Rzymu, chrześcijaństwa ${ }^{37}$, podobnie ma to miejsce we wczesnej literaturze karaimskiej ${ }^{38}$. Określenie to można spotkać także w późniejszych czasach, również w odniesieniu do chrześcijan, na przykład u Abrahama Firkowicza: „nasi bracia, potomkowie Ezawa, chrześcijanie" ${ }^{39}$. Esaw i edom odpowiadają więc sobie znaczeniowo, przy czym pierwszy w języku zachodniokaraimskim jest także określeniem narodowości. Trudno powiedzieć, czy i w jakim zakresie edom funkcjonowało w karaimskim w znaczeniu 'chrześcijanin, chrześcijański', gdyż w takim znaczeniu wyraz ten nie pojawia się w znanych rękopisach, nie odnotowują go także słowniki. W przekładzie Eszwowicza mamy więc do czynienia jednocześnie z odwołaniem się do narodu - jak w oryginale, i do wyznania, czego w oryginale nie ma.

„Królewski szczep piastowy” w czwartym wersie oryginału utracił w karaimskiej wersji konkretne odniesienie historyczne (Piastowie), by zamienić się w ševet bijik jiwden 'plemię z wysokiego domu'. 'Dom' można tu oczywiście rozumieć w sensie dynastycznym, choć Eszwowicz odnosi się raczej do słów z Widzenia Abdiasza mówiących o Edomie: „który na wysokości założyłeś swoją siedzibę” ${ }^{40}$. Biblijni Edomici, potomkowie Ezawa, osiedlili się na górzystej wyżynie Seir, a ich stolica nosiła nazwę Sela (hebr. 'skała'). ${ }^{41}$ Mamy tu więc do czynienia ze specyficzną grą słów - w tym wypadku Eszwowicz skłonił się, niewątpliwie

37 Por. H. Spurling, The Biblical Symbol of Edom in Jewish Eschatological and Apocalyptic Imagery, [w:] Sacred Text: Explorations in Lexicography, red. J. P. Monferrer Sala, A. Urbán, Studien zur romanischen Sprachwissenschaft und interkulturellen Kommunikation, Frankfurt am Main 2009, s. 271-300; L. Ginzberg, The Legends of the Jews, t. V, Philadelphia 1968, s. 272. Niekiedy identyfikowany z Konstantynopolem, zob. The Rabbinic Targum of Lamentations: Vindicating God, Studies in the Aramaic interpretation of Scripture, nr 3, red. Ch. M. M. Brady, Leiden-Boston 2003, s. 127.

38 H. Ben-Shammai, The Attitude of Some Early Karaites towards Islam, „Studies in Medieval Jewish History and Literature" 1984, z. 2, s. 8-23, za: D. Frank, Search Scripture Well. Karaite Exegetes and the Origins of the Jewish Bible Commentary in the Islamic East, Leiden-Boston 2004, s. 17.

39 A. Firkowicz, Kișur tahlit Yešayahu, [w:] Aharon ben Yosef Mivhar yešarim, Gözleve 1834, 45a, za: D. J. Lasker, Karaism and Christianity: an Evolving Relationship, [w:] New Perspectives on Jewish-Christian Relations: In Honor of David Berger, red. E. Carlebach, J. J. Schacter, Leiden-Boston 2012, s. 485.

40 Księga Abdiasza, 1, 3. Pismo Święte Starego i Nowego Testamentu, Poznań: Pallottinum 1971, s. 1076.

${ }^{41}$ W tym miejscu pragnę podziękować dr Mariuszowi Pawelcowi za cenne uwagi dotyczące odwołań biblijnych. 
słusznie, ku ekwiwalencji dynamicznej, odchodząc od oryginału i wprowadzając zrozumiałe dla karaimskiego czytelnika skojarzenie.

W przekładzie Eszwowicza występuje także kilka innych znaczących modyfikacji. Odniesienia do Niemców i germanizacji, nierozerwalnie związane z okolicznościami powstania Roty, znikły w karaimskim przekładzie całkowicie. I tak 'zniemczyć' („Nie damy, by nas zniemczył wróg”) zostało zastąpione przez kyjnałma 'męczyć się, być dręczonym', a „krzyżacka zawierucha” stała się taułu of dusmannyn 'burzą wroga' ('wróg' z zaimkiem określonym). Eszwowicz w swym przekładzie konsekwentnie unika slawizmów, a takim jest Niemic 'Niemiec'42 (określenie Tiłsiz / Til'siż 'pozbawiony języka, niemy' w znaczeniu 'Niemiec' pochodzi, jak się wydaje, dopiero z czasów II wojny światowej ${ }^{43}$ ). Zapewne z tego samego względu ów określony 'wróg' (oł dusman) zajął także miejsce Niemca w wierszu 13 („Nie będzie Niemiec pluł nam w twarz”). Gdyby Eszwowicz zdecydował się dochować wierności oryginałowi, dla 'germanić' („Ni dzieci nam germanił”), jak i dla wspomnianego wcześniej 'zniemczyć', musiałby stworzyć neologizm od zapożyczonego z polskiego Niemica. Dlatego zamiast 'germanić' mamy tu ajłandyrmasty uwułlarymyzny biżin cajałarha 'nie zmieni naszych synów w zuchwalców'. Użycie w tym kontekście caja 'chytry, przebiegły, zwinny, zręczny, zuchwały / bezczelny’ może wskazywać, że w języku potocznym w Haliczu wyraz ten mógł mieć jeszcze jakieś inne znaczenie (np. zdeprawowany?).

W przedostatnim wersie trzeciej zwrotki „złoty róg” („Pójdziem, gdy zabrzmi złoty róg”), symbol czynu z Wesela Wyspiańskiego, został zastąpiony przez pozbawiony dodatkowych znaczeń miwizimiz 'nasz róg', a kategoryczność tej deklaracji osłabiona użyciem trybu warunkowego eǵer tartyłsa.

O ile of sondrahy kanhadejin 'do ostatniej krwi' w miejsce „do krwi ostatniej kropli z żyl” w wierszu 7 wydaje się podyktowane chęcią zredukowania liczby głosek do takiej samej jak w oryginale, to trudniej wytłumaczyć dodanie w następnym wersie do „bronić będziemy ducha” swoistego objaśnienia, dopowiedzenia w postaci syndyrmaktan 'przed złamaniem, rozbiciem', które znacznie wydłużyło wers. Być może Eszwowicz chciał w ten sposób utworzyć paralelną konstrukcję z gufka (dativus od guf, z hebr. 'ciało') w wersie 10: złamanie duszy [ducha] - burza [napór] na ciało. Nie wpłynęło to jednak korzystnie na strukturę wiersza i oddaliło przekład od oryginału.

42 Por. „Turałmahy” Karajłarnyn, „Karaj Awazy” 1938, z. 12, s. 3.

43 Por. Urzeczeni Orientem. Listy Ananiasza Zajaczkowskiego do Tadeusza Kowalskiego 1925-1948, red. T. Majda, Warszawa 2013, s. 197. 


\section{Konkluzja}

Dokonany przez Eszwowicza przekład Roty Konopnickiej nie odznacza się walorami literackimi. Nie oddaje też dokładnie treści oryginału, zwłaszcza odzwierciedlonego w nim kontekstu historycznego. Nieznane są okoliczności, w jakich przekład ten powstał ani cel jego dokonania. Nie da się też stwierdzić, czy jest to finalna wersja, czy też jedynie etap wstępny, przygotowanie do przekładu literackiego. Ponieważ jest to jedyny przykład tego typu utworu w nader skromnym dorobku Eszwowicza, trudno tylko na jego podstawie oceniać sprawność tłumacza. Trzeba jednak przyznać, że nie wydaje się, by posiadał on szczególne uzdolnienia w tym względzie.

Podany przez L. Sulimowicza rok powstania może wskazywać, że przekład ten mógł mieć związek z podjęciem przez Eszwowicza pracy jako nauczyciel religii karaimskiej w szkole powszechnej w Haliczu. Możemy jednak jedynie spekulować, czy w zamyśle tłumacza miał być recytowany przez karaimskich uczniów podczas uroczystości szkolnych lub państwowych.

Fakt istnienia tego przekładu, jak się wydaje, pozostawał szerzej nieznany. Nieadekwatność formy uniemożliwiała śpiewanie tekstu karaimskiego do znanej melodii, co spowodowało, że nie zyskał takiej popularności jak pieśni przełożone przez Z. Abrahamowicza. ${ }^{44}$

Tłumaczenie Roty dokonane przez Eszwowicza, mimo wszystkich swoich niedostatków, pozostaje interesującym przykładem wpływu literatury i kultury polskiej na piśmiennictwo karaimskie.

\section{Bibliografia}

Abrahamowicz, Zachariasz, Hanuz Karajłar eksilmed'. Pieśń na wzór "Jeszcze Polska nie zginęla” "Coś" 1979, z. 2, s. 15.

Abrahamowicz, Zygmunt, Two Religious Poems by the Polish $16^{\text {th }}$ Century Poet Jan Kochanowski in Karaite, „Bulletin d'Études Karaïtes” 1989, z. 2, s. 65-82.

Adam Mickiewicz-nin «Kyrym sonetłary». Karaj śoźuna k’ocźurd'u Ananjasz Zajaczkowski, [przekład: Ananiasz Zajączkowski], „Karaj Awazy” 1931, z. 1, s. 10-13.

Adam Mickiewiczniń «Kyrym sonetłary» (Karaj śoźuńa k’ocźurm'agi), [przekład: Ananiasz Zajączkowski], „Karaj Awazy” 1931, z. 2, s. 14-17.

${ }_{44}$ Podczas pobytu w Haliczu w 1989 r. autorka miała okazję wysłuchać tych pieśni w wykonaniu blisko 90-letniej Liny z Mordkowiczów Ickowicz (1901-1991), Karaimki z Załukwi. 
Alpuhara. Adam Mickiewicznin balladasy azat kecirmeginde Al-Marnyn, [przekład: Aleksander Mardkowicz], „Karaj Awazy” 1935, z. 8, s. 8.

Ben-Shammai, Haggai, The Attitude of Some Early Karaites towards Islam, „Studies in

Medieval Jewish History and Literature" 1984, t. 2, s. 3-40,

Bir kiuń èdi... Buvo tokia diena..., red. H. Kobeckaitė, K. Firkavičiutè, Vilnius 2015.

Dubiński, Aleksander, Przekłady literatury polskiej w piśmiennictwie karaimskim, „Przegląd Orientalistyczny" 1975, 4 (96), s. 403-404.

Dzymatynda Halicnin, „Karaj Awazy” 1934, z. 7, s. 25.

Firkowicz, Szymon, Kołtchałar. Krótkie modlitwy karaimskie, Wilno 1935.

Frank, Daniel, Search Scripture Well. Karaite Exegetes and the Origins of the Jewish Bible Commentary in the Islamic East, Études sur le judaïsme médiéval, nr 29, Leiden 2009. Ginzberg, Louis, The Legends of the Jews, Philadelphia 1968.

Grzegorzewski, Jan, Caraimica. Jezyk Łach-Karaitów. Narzecze południowe (łuckohalickie), „Rocznik Orientalistyczny” 1914-1918, t. 1-2, s. 252-296.

Ir-awazy igitlikkia (Adam Mickiewicz, Oda do młodości), [przekład: Szymon (Szemaja) Firkowicz], „Cos” 1979, z. 2, s. 6-11.

Joł kała iuśtiunia (Adam Mickiewicz, Droga nad przepaścia w Czufut Kale), [przekład: Szymon (Szemaja) Firkowicz], „Myśl Karaimska” 1925, t. 1, z. 2, s. 24.

Karaimsko-russko-pol'skij slovar', red. N. A. Baskakov, A. Zajączkowski, S. M. Szapszał, Moskwa 1974.

Kowalski, Tadeusz, Karaimische Texte im Dialekt von Troki, Prace Komisji Orjentalistycznej Polskiej Akademji Umiejętności, nr 11, Kraków 1929.

Kowalski, Tadeusz, Materjały karaimskie ś. p. Jana Grzegorzewskiego, „Myśl Karaimska” 1932-1934, t. 10, z. 10, s. 24.

Leszczyński, Rafał, Wiersze Jana Kochanowskiego w przekładach na język karaimski, [w:]

Poeta z Czarnolasu. W czterechsetna rocznice śmierci Jana Kochanowskiego, red. P. Buchwald-Pelcowa, J. Pacławski, Radom 1984, s. 51-60.

Mardkowicz, Aleksander, Zemerłer. Pieśni religijne Karaimów, Łuck 1930.

Mardkowicz, Aleksander, Karaj sez bitigi. Słownik karaimski. Karaimisches Wörterbuch, Łuck 1935.

[Mardkowicz, Aleksander], „Turałmahy” Karajłarnyn, „Karaj Awazy” 1938, z. 12, s. 3.

Pan Tadeusz. Inwokacja (Adam Mickiewicz), [przekład: Józef Łobanos], „Awazymyz” 2004, z. 1 (8), s. 6.

Pismo Święte Starego i Nowego Testamentu, Poznań: Pallottinum 1971.

Smólski, Grzegorz, U Karaimów w Haliczu, „Naokoło Świata” 2, s. 465-467, 482-484, 506-507, 522-253, 538-540, 546-548, 564-565. Przedruk w: Almanach karaimski, red. M. Abkowicz, A. Sulimowicz, [Wrocław] 2007, s. 71-84.

Spurling, Helen, The Biblical Symbol of Edom in Jewish Eschatological and Apocalyptic Imagery, [w:] Sacred Text: Explorations in Lexicography, red. J. P. Monferrer Sala, A. Urbán, Studien zur romanischen Sprachwissenschaft und interkulturellen Kommunikation, Frankfurt am Main 2009, s. 271-300. 
The Rabbinic Targum of Lamentations: Vindicating God, Studies in the Aramaic interpretation of Scripture, nr 3, red. Ch. M. M. Brady, Leiden-Boston 2003.

Urzeczeni Orientem. Listy Ananiasza Zajaczkowskiego do Tadeusza Kowalskiego 1925-1948, red. T. Majda, Warszawa 2013.

Ücz budrys (Adam Mickiewicz, Trzech budrysów), [przekład: Szymon (Szemaja) Firkowicz], „Coś” 1979, z. 1, s. 6-9.

Zajączkowski, Ananiasz, Die karaimische Literatur, [w:] Philologiae Turcicae Fundamenta, t. II, red. L. Bazin, A. Bombac1, J. Deny, T. Gökbilgin, F. İz, H. Scheel, P. N. Boratav, Wiesbaden 1964, s. 793-801.

Zecharja Abrahamowicznin tiziwteri, „Karaj Awazy” 1931, z. 2, s. 24-29.

Halicz, „Myśl Karaimska” 1924, t. 1, z. 1, s. 34.

Zarachowicz, Zarach, Listy z Halicza, „Myśl Karaimska” 1924, t. 1, z. 1, s. 26-30.

Zarachowicz, Zarach, Nauczanie religji karaimskiej, „Myśl Karaimska” 1925, t. 1, z. 2, s. 41-42.

Z[arach] Z[arachowicz], Otwarcie szkoly parafialnej, „Myśl Karaimska” 1926, t. 1, z. 3, s. 26. 


\section{Facsimile}

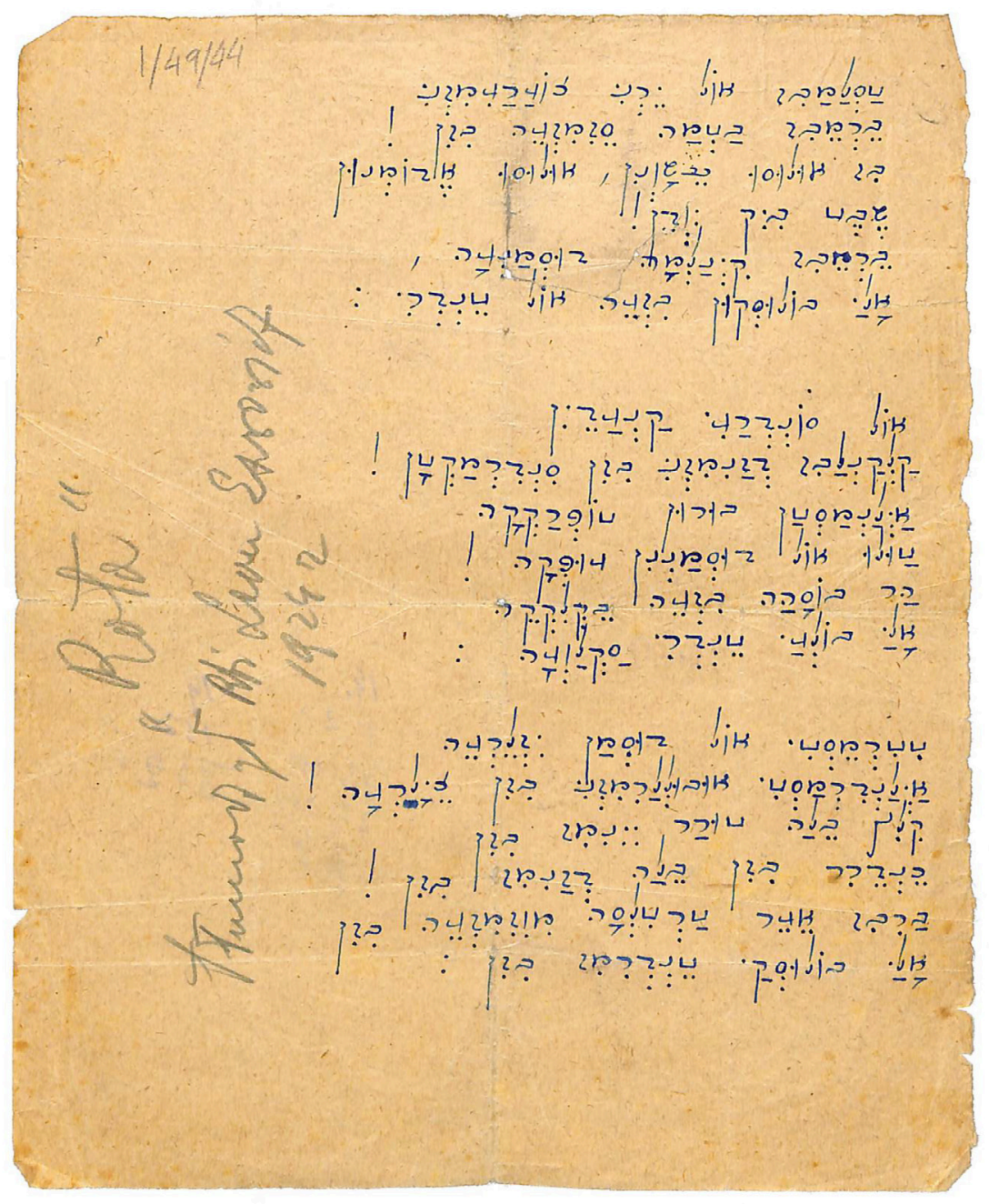

